\title{
ACCELERATION OF DIGITAL TRANSFORMATION AS A RESULT OF LAUNCHING PROGRAMS FINANCED FROM PUBLIC FUNDS: ASSESSMENT OF THE IMPLEMENTATION OF THE OPERATIONAL PROGRAM DIGITAL POLAND
}

\author{
Miroslaw MOROZ \\ Wroclaw University of Economics, Faculty of Economic Sciences, Wroclaw, POLAND \\ e-mail: miroslaw.moroz@ue.wroc.pl
}

\begin{abstract}
The main purpose of the paper is to assess the current implementation of the Operational Program Digital Poland in terms of coherence with the trends of digital transformation. The Operational Program Digital Poland (OPDP) is one of the programs financed from public funds, which is directly targeted at the development of the digital economy in Poland. At the end of 2017, the implementation of the program is at the halfway point, which gives the premise to reflect on the degree of convergence of goals and program implementation with the trends of digital transformation. The research methodology is based on the analysis of secondary sources and participant observation. The results of the analysis show that the results of actions undertaken under the OPDP in principle indirectly contribute to the progressing trend of digitization of the Polish economy. The structure of expenditures under the OPDP testifies to the relative shallow rooting of the digital transformation or, more broadly, the digital economy in Poland.
\end{abstract}

Keywords: digital transformation, Operational Program Digital Poland, Public structural expenditure, Poland.

JEL: O33, O38, M21, L81, M15.

\section{Introduction}

The broadly understood digitization of personal, social and economic life is constantly increasing its scope. The use of information and communication technologies contributes to a more complete saturation with information, integration of various areas of knowledge, faster decision-making, the emergence of new business models or e-government services. As a consequence, the modern world performs the so-called digital transformation.

In simplification, the phenomenon of digital transformation reflects the transition from the traditional (industrial, service) economy towards an economy based more and more on online information. Information has always been the basis for making decisions. Economic decisions are also based on data analysis and drawing conclusions from them. What distinguishes the digital economy from the traditional economy is the specificity of access to information created by the spread of the Internet and access devices, such as a Smartphone, tablet or computer. With today's degree of saturation with Internet ac- cess, you can point to the following features of online information:

- available in real time,

- available non-stop,

- widely available (the scope of existing digital data and the ease of searching digital content),

- integrated (logically related data from many sources),

- ease of maintenance (cloud computing),

- ease of processing (increasing computing power, machine learning, artificial intelligence).

These online information features form the framework of the digital economy and enable the advancement of digital transformation. According to the data presented by the consulting company Accenture, the share of digital economy in the creation of global gross domestic product amounted to $22.5 \%$ in 2015 (Knickrehm, et al., 2016).

This result is based on the use of digital skills, digital entrepreneurship and digital technologies. What is more, according to cautious forecasts, in the perspective of 5 years, the share of the digital economy in GDP creation is to increase to $25 \%$ (ibidem). 
This confirms the already existing economic importance of the digital economy, as well as emphasizes the potential of digital transformation in the future.

With the current state of civilization development, the process of transition to the digital economy is irreversible. Digital transformation takes place through the emerging trends related to technological, social and economic aspects of the use of information and communication technology. However, there is no universally accepted view of what factors make up the digital transformation. Therefore, for the purpose of this study, an original concept of the structure of digital transformation will be proposed, reflecting the most important trends in the transition to the digital economy.

The pace of digital transformation can be moderated by pursuing a specific economic policy. One of the examples of economic programs focused on the development of digital economy is the Polish Digital Operational Program (OPDP). The aim of the program is to strengthen digital foundations for national development (Operational, 2014). The program in question is currently (at the end of 2017) at the halfway point of its implementation. This leads to the analysis of the degree of coherence between the current implementation of the program and the identified trends of digital transformation.

The main purpose of the paper is to assess the current implementation of the Operational Program Digital Poland in terms of its coherence with the trends of digital transformation.

The methodology of the conducted research is based on the analysis of secondary sources and participant observation. The first method was used for qualitative data analysis referring to the trends of digital transformation and the progress of the Operational Program Digital Poland. The second method was used to look "from the inside" on the implementation process of the said program. The author was an evaluation expert in two OPDP measures: 1.1 and 2.1.

The analysis is based on data from the years 20142017.

\section{Digital transformation - the being and conditioning}

Digital transformation is a phenomenon that occurs with the growing use of information and communication technologies. Dissemination of the Internet for information, communication, transactional and financial purposes; generating ever larger volumes of digital content based on devices based on digital data flow (computers, tablets, smartphones, digital cameras, smart TV, etc.); improving network technologies; more and more computational capabilities of processors - these are just some of the factors that create digital transformation.

The term "digital transformation" is not uniformly recognized in the literature. This undoubtedly results from the interdisciplinary character of the concept, referring to technological, social and business aspects. There is also the issue of entities implementing the transition to digital realities. Generally, the mentioned term is assigned to enterprises. It happens, however, that the digital transformation is also spreading through public entities (Karatzogianni, et al., 2016). Thirdly, digital transformation is a process that takes place constantly, about the scope moving along with the progress of digitization. Table 1 presents the selected definitions of digital transformation.

The above-mentioned definitions put emphasis on two key aspects of digital transformation: the use of information and communication technologies (ICT) and the improvement of the organization's efficiency. ICT are regarded as the main factor triggering the digital transition. IT technologies allow you to:

- streamlining the decision making by minimizing the information asymmetry phenomenon,

- automation of many activities in the intangible value chain, appropriate for most modern enterprises,

- collecting, processing and using large data sets, obtained from many sources of various formats,

- immediate and very cheap communication, exchange of knowledge and ideas,

- launching of a new sales channel (e-commerce), and for distribution of non-material products as well, 
Table 1. The notion of digital transformation

(Source: Cap Gemini, 2011; Hanna, 2016; Bracken, 2016; Christensen, 2016; Mazzone, 2014;

Herbert, 2017; Forbes Insight, 2017; Hanelt, et al., 2015)

\begin{tabular}{|r|l|}
\hline \multicolumn{1}{|c|}{ Author } & \multicolumn{1}{c|}{ Definition } \\
\hline G. Westerman, et al. & The use of technology to radically improve performance or reach of enterprises \\
\hline N.K. Hanna & $\begin{array}{l}\text { Deep structural changes in the economy and society brought about by harnessing } \\
\text { the full potential of the ICT revolution }\end{array}$ \\
\hline M. Bracken & $\begin{array}{l}\text { Applying the culture, practices, processes and technologies of the Internet era } \\
\text { to respond to people's raised expectations }\end{array}$ \\
\hline J. Christensen & $\begin{array}{l}\text { The way in which organizations perceive and manage their assets, as products } \\
\text { and services are enhanced with digital capabilities that increase their value }\end{array}$ \\
\hline D.M. Mazzone & $\begin{array}{l}\text { The deliberate an ongoing digital evolution of a company, business model, idea, process } \\
\text { or methodology; both strategically and tactically }\end{array}$ \\
\hline L. Herbert & $\begin{array}{l}\text { A company's ability to react and successfully utilize new technologies and procedures - } \\
\text { now and in the future }\end{array}$ \\
\hline R. Gagnon, et al. & Digital transformation uses technology as a means, not an end \\
\hline A. Hanelt, et al. & $\begin{array}{l}\text { The employment of new digital technologies to foster major business improvements } \\
\text { in organizations }\end{array}$ \\
\hline
\end{tabular}

- creating new business models and virtual entrepreneurship.

The use of ICT changes the way man works, rests, buys, travels, interacts and so on, which in turn translates into the functioning of enterprises and societies.

Digitalization imposes a mark on almost every aspect of modern life. Against this background, one can see the transformational (breakthrough) nature of ICT technologies. Table 2 identifies seven factors that create breakthrough technology.

Technology can be perceived as transformational if it includes three or more factors indicated in Table 2 (ibidem). ICT meets all the seven factors listed.

In the economic sense, the use of information and communication technologies generates a number of benefits, such as (Herbert, 2017; Combe, 2006):

- more profitable business models,

- more efficient operating processes,

- enhancing value proposition,

- new sources of revenue,

- automated processes,

- lower cost of exchange of information,
- ease of access to broader market,

- networked externalities.

On the other hand, it should be remembered that the transition from the digital organization is not a prosaic process (Combe, 2006, p.3). Digital transformation is associated with many barriers and challenges. The most frequently mentioned are (Forbes Insight, 2017; Eggers, Bellman, 2016):

- legacy technologies,

- lack of talent throughout the enterprise,

- lack of collaboration on data and analytics,

- lack of vision and strategy,

- low IT department readiness to adopt and support digital transformation,

- inability to clearly demonstrate ROI,

- insufficient funding,

- security concerns,

- lack of organizational agility,

- lack of entrepreneurial spirit and lack of willingness to take risks. 
Table 2. Transformation Criteria and Examples

(Source: Lucas, et al., 2013)

\begin{tabular}{|c|c|c|c|}
\hline & Individual & Business & Economy/Society \\
\hline Process & $\begin{array}{l}\text { A change in a personal } \\
\text { process of more than half } \\
\text { the steps (e.g., digital pho- } \\
\text { tography) }\end{array}$ & $\begin{array}{l}\text { A change in a business } \\
\text { process of more than half } \\
\text { the steps (e.g., book publish- } \\
\text { ing vs. e-books) }\end{array}$ & \\
\hline $\begin{array}{c}\text { New } \\
\text { organizations }\end{array}$ & & $\begin{array}{l}\text { Creation of a new organiza- } \\
\text { tion with a value of at least } \\
\$ 100 \text { million (e.g., Amazon, } \\
\text { Facebook, and Google) } \\
\text { or multiple organizations } \\
\text { (e.g., Health Information } \\
\text { Exchanges) }\end{array}$ & $\begin{array}{l}\text { Creation of a new organi- } \\
\text { zation that changes at least } \\
\text { two hours of individual } \\
\text { behavior a day (mobile } \\
\text { communications and web) }\end{array}$ \\
\hline Relationships & $\begin{array}{l}\text { A change in social relations } \\
\text { affecting at least half } \\
\text { of one's contacts or doubling } \\
\text { the number of contacts (e.g., } \\
\text { Facebook) }\end{array}$ & $\begin{array}{l}\text { A change affecting at least } \\
\text { half of relationships with } \\
\text { other organizations or a dou- } \\
\text { bling of the number of rela- } \\
\text { tionships (e.g., iTunes for } \\
\text { Apple, e-books for Amazon) }\end{array}$ & $\begin{array}{l}\text { A change affecting at least } \\
\text { two hours of individual } \\
\text { behavior a day related } \\
\text { to social relations (e.g., } \\
\text { Facebook, Twitter) }\end{array}$ \\
\hline $\begin{array}{c}\text { User } \\
\text { Experience }\end{array}$ & $\begin{array}{l}\text { A change in user experience } \\
\text { involving at least } 2 \text { hours } \\
\text { per day (e.g., Facebook) }\end{array}$ & & \\
\hline Markets & $\begin{array}{l}\text { A change in at least half } \\
\text { of one's vendors in a particu- } \\
\text { lar market (e.g., iTunes vs. } \\
\text { CD purchases) }\end{array}$ & $\begin{array}{l}\text { Entering or leaving at least } \\
\text { one market served by the } \\
\text { firm (a.k.a. iDevices) }\end{array}$ & $\begin{array}{l}\text { Creation of a new market } \\
\text { with at least } \$ 100 \text { million } \\
\text { of transactions a year } \\
\text { (such as music download- } \\
\text { ing, search advertising) }\end{array}$ \\
\hline Customers & & $\begin{array}{l}\text { A change in which the firm } \\
\text { serves at least } 50 \% \text { more } \\
\text { customers (e.g., Amazon e- } \\
\text { books, iTunes) }\end{array}$ & \\
\hline $\begin{array}{l}\text { Disruptive } \\
\text { impact }\end{array}$ & & $\begin{array}{l}\text { A change that forces at least } \\
\text { one competitor to move from } \\
\text { a profit to a loss, exit a mar- } \\
\text { ket, enter a merger or declare } \\
\text { bankruptcy (e.g., Netflix vs. } \\
\text { Blockbuster, e-books vs. } \\
\text { Borders, digital photography } \\
\text { vs. Kodak) }\end{array}$ & $\begin{array}{l}\text { Reduction of at least } \$ 100 \\
\text { million in transactions } \\
\text { a year in a market (e.g., } \\
\text { print newspaper circula- } \\
\text { tion) }\end{array}$ \\
\hline
\end{tabular}


The above list clearly shows that the basic barriers to the implementation of digital transformation do not result from technological, but organizational, cultural and management aspects. It is worth to pay attention to these aspects when preparing for the digital transition.

Summing up this part of the study, the author will treat digital transformation as the process of transition from traditional economy to digital economy using information and communication technologies to improve the results of a given organization.

\section{Components of a Digital Transformation}

The result of implementing the digital transformation is the expansion of the scope of using information and communication technologies in the daily functioning of the organization. However, the number of possible applications of digital devices, types of software, programming algorithms and their interaction with the user is so large that it is necessary to consider structuring the phenomenon of digital transformation. In other words, there is a need to the identify key components that in practice create digital transformation.

The issue of the components of digital transformation is relatively rarely undertaken in the devoted literature. The query conducted by the author showed three concepts/models identifying more precisely the most important elements of the digital transition. Tables 3, 4 and 5 contain elements of each identified concept.

The presented concepts indicate what constitutes a digital transformation. As a matter of fact, the presented concepts are based on an analytical approach: they divide and order a broad phenomenon that is a digital transition to components. Irrespective of the criterion of division, there are some recurring elements. They include customer expectations, business models, data-driven decision making, improved business processes and data integration. The above common set of components, as well as the author's observations, induce to present the author's concept of structuring digital transformation. Table 6 presents the meta-concept of the components of digital transformation.

Table 3. Components of digital transformation according to the World Economic Forum \& Accenture (Source: Digital Transformation Initiative, 2017)

\begin{tabular}{|c|c|}
\hline Primary layer & Secondary layer \\
\hline Digital consumption & $\begin{array}{l}\text { - Products and services to experience: delivering the most compelling experiences } \\
\text { - Hyper-personalization: personalized interactions at all points of customer journey } \\
\text { - Ownership to access: customer preferences for access-based models }\end{array}$ \\
\hline Digital enterprise & $\begin{array}{l}\text { - Digital business models: change the way in which organization identify, develop } \\
\text { and launch new business initiatives } \\
\text { - Digital operating models: change the operational processes } \\
\text { - Digital talent and skills: new digital skills are needed } \\
\text { - Digital metrics for success: effective performance indicators for the digital world }\end{array}$ \\
\hline Platform economy & $\begin{array}{l}\text { - Driving transformed business models: utilizing network effects } \\
\text { - Helping ecosystems expand: blurring industry boundaries and reshaping industry } \\
\text { into interconnected systems } \\
\text { - Creating a win-win strategy for industry and society: society is expected to gain } \\
\text { as much as industry (through new jobs, benefits for the consumer) }\end{array}$ \\
\hline
\end{tabular}


Table 4. Components of the digital transformation according to Capgemini (Source: Digital Transformation, 2017)

\begin{tabular}{|c|c|}
\hline Primary layer & Secondary layer \\
\hline Customer experience & $\begin{array}{l}\text { - Customer understanding: analytics-based segmentation } \\
\text { - Digitally-enhanced selling: predictive algorithms } \\
\text { - Customer touch points: cross-channel coherence and self service }\end{array}$ \\
\hline Operational process & $\begin{array}{l}\text { - Process digitization: streamlined processes and new features } \\
\text { - Worker enablement: working anywhere anytime, knowledge sharing broader } \\
\text { communication } \\
\text { - Performance management: data-driven decision making }\end{array}$ \\
\hline Business Model & $\begin{array}{l}\text { - Digitally modified businesses: transitioning physical to intangible and prod- } \\
\text { uct/service augmentation } \\
\text { - New digital businesses: new ventures, new digital products } \\
\text { - Digital globalization: shared digital services, broader integration, redistribution } \\
\text { decision authority }\end{array}$ \\
\hline Digital Capabilities & $\begin{array}{l}\text { - Analytics capability } \\
\text { - Unified data and processes } \\
\text { - Business and IT integration }\end{array}$ \\
\hline
\end{tabular}

Table 5. Components of the digital transformation according to MIT Center for Digital Business \& Capgemini (Source: Soule, et al., 2016)

\begin{tabular}{|c|l|}
\hline Primary layer & \multicolumn{1}{|c|}{ Secondary layer } \\
\hline \multirow{2}{*}{ Practices } & - Digitized operations: intangible operation and documentation \\
& - Data-driven decisions: systematic experimentation, analysis and decision-making \\
& - Collaborative learning: boundary-crossing collaboration \\
\hline Workforce & $-\begin{array}{l}\text { Technology experience: literacy that support analytical intensity } \\
\text { and social connectivity }\end{array}$ \\
& - Digital skills: knowledge when and how to launch initiatives \\
& - High engagement: self-motivated and entrepreneurial approach \\
\hline Resources & - Real-time custom data: ability to access and interact with real-time customer data \\
& $-\begin{array}{l}\text { Integrated operations data: ability to access and interact } \\
\text { with comprehensive operations data }\end{array}$ \\
\hline & Collaborations tools: digital support for communication and coordination \\
\hline
\end{tabular}


Table 6. Meta-conception of components of digital transformation

(Source: Own elaboration)

\begin{tabular}{|c|l|}
\hline Primary layer & \multicolumn{1}{|c|}{ Solutions, methods and techniques } \\
\hline Change in buying behavior & Eliminating information asymmetry, immediacy, self-service (prosuments) \\
\hline Automation and autonomy & Internet of Things, Machine Learning, Artificial Intelligence \\
\hline $\begin{array}{c}\text { Comprehensive / up-to-date } \\
\text { data }\end{array}$ & $\begin{array}{l}\text { Predictive algorithms, Business analytics, Cloud computing, Big Data, } \\
\text { Business Intelligence }\end{array}$ \\
\hline $\begin{array}{c}\text { Changes in business models } \\
\begin{array}{c}\text { The emergence of new } \\
\text { segments of the economy }\end{array}\end{array}$ & E-commerce, Omnichannel, Online accounting \\
\hline $\begin{array}{c}\text { Improving digital competences } \\
\text { Sharing economy, social media marketing }\end{array}$ & Information competences, functional competences, IT competences \\
\hline
\end{tabular}

The proposed concept is based on six components. The elements taken into account refer to a broad spectrum of issues related to digital transformation. On the one hand, they include advanced techniques and programming methods such as machine learning, artificial intelligence or autonomous devices. On the other hand, they take into account human competences and behaviors, both after the demand (customer) and supply (employee) side. Economical aspects also found their place in the concept. At the same time, the concept in question is characterized by a certain degree of gradation. Some of the presented solutions can be implemented at small expenses. Others, in turn, require large expenses. Thanks to such accents, it is possible to look at digital transformation through the prism of key digital transition trends.

\section{Characteristics and status of implementa- tion of the Operational Program Digital Poland}

Creating and promoting digital solutions is one of the main objectives of the European Union. The European Union authorities recognize the importance of information and communication technologies for the social and economic development of the Member States. Available data indicates that (European Commission, 2010):

- $90 \%$ of jobs will require basic information technology skills,
- The Internet economy creates five jobs for every two "offline" jobs lost,

- The EU digital economy is growing at $12 \%$ each year and is now bigger than the Belgian national economy,

- There are more mobile phone subscriptions in the EU than people,

- There are 7 million jobs in the ICT sector in Europe,

- It is estimated that half of productivity growth derives from investment in ICT.

An expression of appreciation for the role of ICT is the inclusion of ICT-related development trends in the Europe 2020 strategy (priority "Intelligent development - development of knowledge-based economy and innovation") (European Commission, 2014), as well as the launch in May 2010 of Digital Agenda for Europe - a program directly supporting the digitization processes of the European Union.

In the 2014-2020 programming period, Poland received EU financial support at the level of over 86 billion Euros. Some of these funds were allocated to the digitization of the state. The Operational Program Digital Poland became a practical instrument of digitization. The reasons for launching the program were related to the delay of Poland compared to the European Union in terms of the scope and pace of ICT use. In 2012, the percentage of households with Internet access in Poland amounted to $69.1 \%$, with the average for the European Union countries 
at $95.5 \%$. If we take into account the Internet with a bandwidth of at least $30 \mathrm{MB} / \mathrm{s}$, in Poland it was $44.5 \%$ with the EU average of $53.8 \%$ (Holubowicz, et al., 2013).

The level of advancement of public e-services in 2010 was lower than the EU average (for business services, this level reached $90 \%$ with the EU average of $94 \%$, for services for citizens $85 \%$ and $87 \%$ respectively) (ibidem).

The objective of the Operational Program Digital Poland (OPDP) was defined as the strengthening of digital foundations for the country's development through:

- increasing the common access to broadband Internet (> $30 \mathrm{MB} / \mathrm{s})$,

- increasing the quality and availability of public e-services,
- improving the availability of information and public resources,

- improving the quality of human capital and combating digital exclusion.

In the course of conceptual and analytical work, it was stated that the range of intervention would be in line with the conditions in Poland. As a consequence, three main thematic areas of OPDP were adopted, defined as priority axes. They include:

1) common access to high-speed Internet;

2) e-government and open government;

3) digital competences of the society.

Areas of intervention were subject to further decomposition into individual measures, which is included in Table 7.

Table 7. Decomposition of Operational Program Digital Poland (Source: Own elaboration)

\begin{tabular}{|c|c|c|}
\hline Priority axes & Measures No. & Measures' scope \\
\hline I & 1.1 & $\begin{array}{l}\text { Eliminating territorial differences in terms of access to highspeed } \\
\text { and ultra-fast broadband Internet }\end{array}$ \\
\hline \multirow{4}{*}{ II } & 2.1 & High availability and quality of public e-services \\
\hline & 2.2 & Digitization of back-office processes in government administration \\
\hline & 2.3 & Digital availability and usefulness of public sector information \\
\hline & 2.4 & $\begin{array}{l}\text { Creation of services and applications using public e-services and public- } \\
\text { sector information }\end{array}$ \\
\hline \multirow{4}{*}{ III } & 3.1 & Training activities for the development of digital competences \\
\hline & 3.2 & Innovative solutions for digital activation \\
\hline & 3.3 & $\begin{array}{l}\text { e-Pionier - support for talented programmers to solve identified social } \\
\text { or economic problems }\end{array}$ \\
\hline & 3.4 & $\begin{array}{l}\text { Education and information campaigns for dissemination of benefits } \\
\text { from the use of digital technologies }\end{array}$ \\
\hline
\end{tabular}


The above list indicates the scope of works under the OPDP. Co-financing covered the construction of telecommunications infrastructure for the needs of broadband Internet access, the promotion of e-government and the provision of public data, various types of training to improve the skills of finding a digital world.

The OPDP budget is a total of EUR 2,566 billion. (Ministerstwo Rozwoju, 2017). OPDP is a nation- wide operational program financed by the European Regional Development Fund (ERDF). The European Union's contribution is definitely dominant and amounts to over $84.64 \%$. The remaining financial resources come from domestic, mainly public, but also private funds (e.g., own funds of the beneficiary being a private entity). The detailed structure of the division of funds into thematic axes is presented in Table 8.

Table 8 . Structure of expenditures by individual priority axes

(Source: Ministry of Infrastructure and Development, 2014)

\begin{tabular}{|c|c|c|}
\hline Priority axes & EU funding (euro) & Share of OPDP budget \\
\hline I & 1020222652 & $46.96 \%$ \\
\hline II & 949604018 & $43.71 \%$ \\
\hline II & 145000000 & $6.67 \%$ \\
\hline IV & 57668000 & $2.65 \%$ \\
\hline Total: & 2172494670 & $100.00 \%$ \\
\hline
\end{tabular}

The largest amount was reserved for the purpose of building Internet access infrastructure. The second place was the financing of measures aimed at improving e-administration. A small percentage of the program budget was provided for training. The priority axis IV was not substantive (it did not finance beneficiaries) and its task was to raise funds for OPDP management.

The planned results of ODPD implementation concern (Regional Policy, 2013):

- all Polish households having access to high-speed broadband connection,

- increased use of internet in contacts with public administration by citizens and enterprises: $50 \%$ of people and over $90 \%$ of companies using internet in contacts with public administration,

- more robust public e-services,

- better access to public service information,

- increase of the share of regular internet users to more than $80 \%$,
- sharp reduction in the number of people who have never used the internet,

- increased level of digital competences.

The first ODPD tender was announced on December 31, 2014. Until September 30, 2017, a total of 26 calls were announced. 19 of them were completed, of which 17 were resolved. The other two calls ended in July and August 2017 (Ministerstwo Cyfryzacji, 2017b).

230 contracts were signed for co-financing projects under the three priority axes. Table 9 contains examples of projects that have been co-financed by the program.

Project selected in a random manner were presented. The data contained in Table 8 show that the scope of co-financing can vary significantly. Co-financing has been granted to various types of entities: from state institutions, through non-profit organizations, and to private enterprises. The completion of projects is planned for the year 2018 at the earliest, although most projects will end in the following years (2019, 2020). 
Table 9. Selected projects co-financed under the OPDP

(Source: Ministerstwo Cyfryzacji, 2017a)

\begin{tabular}{|c|c|c|c|c|}
\hline Measure & Project name & $\begin{array}{l}\text { Beneficiary } \\
\text { name }\end{array}$ & $\begin{array}{c}\text { Total value } \\
\text { of project }\end{array}$ & $\begin{array}{l}\text { Project } \\
\text { end date }\end{array}$ \\
\hline 1.1 & $\begin{array}{l}\text { Providing access to broadband Internet } \\
\text { with high bandwidth } \\
\text { in the Lubin county }\end{array}$ & SPRAY S.A. & PLN $6.687 \mathrm{mn}$ & $09 / 30 / 2018$ \\
\hline 2.1 & $\begin{array}{l}\text { Development of digital services catalog } \\
\text { for clients of the Tax Administration } \\
\text { and Fiscal Control } \\
\text { in the scope of centralization of CIT } \\
\text { and VAT tax service } \\
\text { as well as support } \\
\text { for the Single Control File (CVP Project) }\end{array}$ & $\begin{array}{l}\text { Ministry } \\
\text { of Finance }\end{array}$ & PLN $97.615 \mathrm{mn}$ & $03 / 20 / 2019$ \\
\hline 2.3 & $\begin{array}{l}\text { EpiBaza - Access to the resources } \\
\text { of the National Epidemiological } \\
\text { and Environmental Supervision System } \\
\text { for the Security of Population }\end{array}$ & $\begin{array}{c}\text { National Institute } \\
\text { of Hygiene }\end{array}$ & PLN 25.533mn & $07 / 31 / 2019$ \\
\hline 3.1 & E-citizen: new digital skills & $\begin{array}{c}\text { National Chamber } \\
\text { of Commerce }\end{array}$ & PLN $10.419 \mathrm{mn}$ & $11 / 30 / 2018$ \\
\hline 3.2 & Program your future $\# 6$ & $\begin{array}{c}\text { Orange } \\
\text { Foundation }\end{array}$ & PLN $0.763 \mathrm{mn}$ & $10 / 31 / 2018$ \\
\hline 3.3 & $\begin{array}{l}\text { e-Pionier - support } \\
\text { for talented programmers } \\
\text { to solve identified social } \\
\text { or economic problems }\end{array}$ & $\begin{array}{l}\text { The National Cen- } \\
\text { tre for Research } \\
\text { and Development }\end{array}$ & PLN 131.175mn & $12 / 31 / 2020$ \\
\hline
\end{tabular}

The total contracted amount of co-financed projects amounted to over PLN 4.86 billion from the EU funds ( $52.5 \%$ of the program budget).

The sum of co-financing for the contracted projects was:

- in axis I-PLN 3.2 billion,

- in axis II - PLN 1.4 billion,

- in the 3rd axis - PLN 0.177 billion.

The increase in the volume of allocated financial resources is reflected in Figure 1.
Until the fourth quarter of 2016, the main measure for which funds from the program were spent were actions from the second thematic axis.

At the end of 2016, the first priority axis started to be put into operation. The third axis financing is relatively small. In turn, in the second priority axis, due to the withdrawal of projects, there was a decrease in the total value of the funded projects.

The volume of expenditure indicates a clear dominance of measure 1.1. An outsider is the expenditure on training, which is, however, compatible with the planned small amount of expenditure for the third axis. 


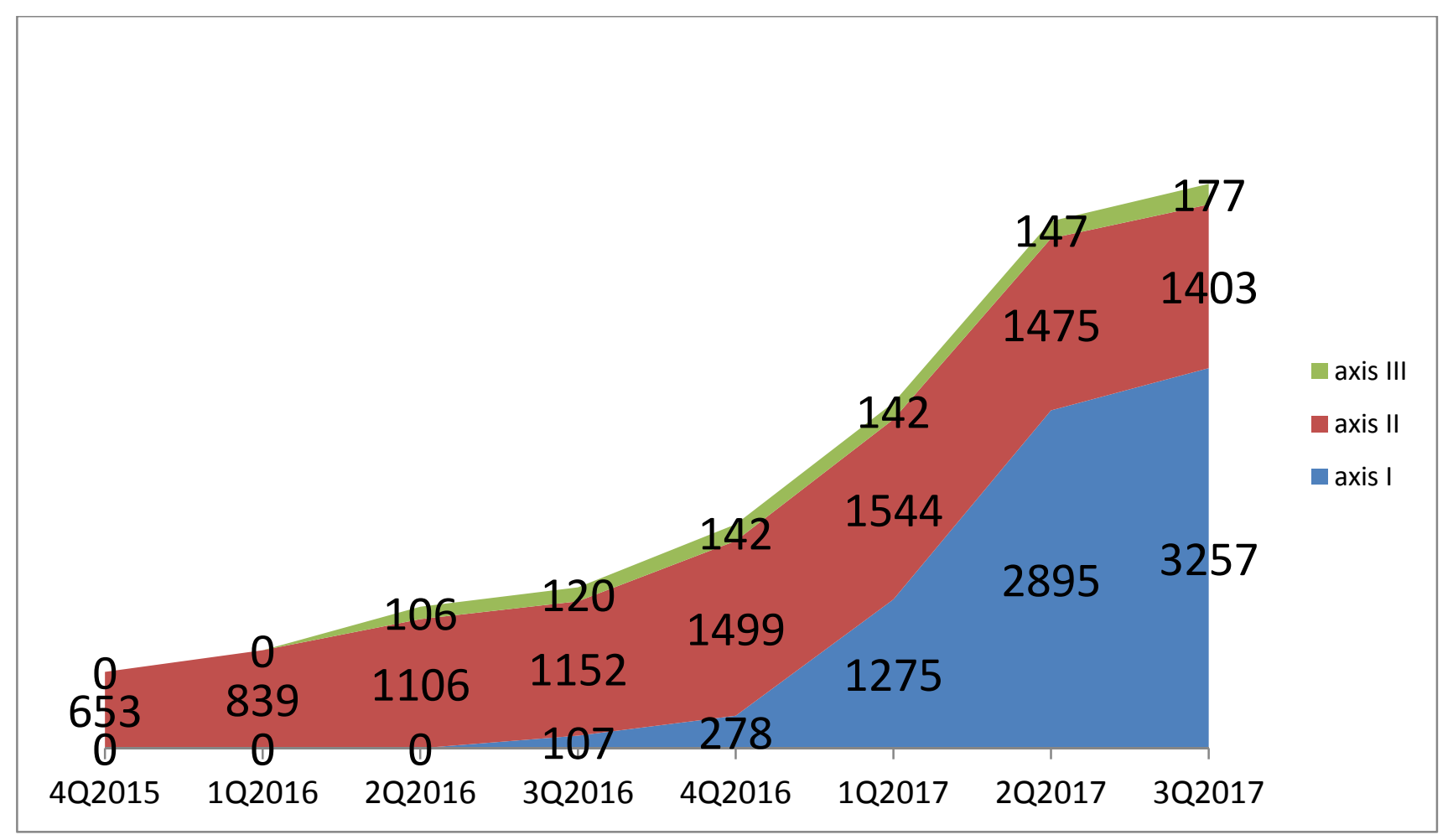

Figure 1. Accumulated value of co-financed projects in millions PLN

(Source: Ministerstwo Cyfryzaji, 2017b)

\section{Coherence of the OPDP with the meta- concept of the components of digital transformation}

The main objective of the article is to assess the current implementation of the Operational Program Digital Poland in terms of coherence with the trends of digital transformation (included in the metaconcept). To achieve such a goal, the author will use two research methods: critical analysis of documentation and participant observation.

The first method is a classic research method used in the analysis and evaluation of secondary data.

The second method results from the fact that the author was an expert evaluating projects in two thematic areas: the first and the second priority axis.

As a matter of fact, OPDP is aimed at popularizing the digital economy. However, the question arises on how the previously identified meta concept of the components of the digital transformation coincides with the designated goal, scope and method of implementing the OPDP.
The mentioned program is a part of the digital transformation process through:

1. the expansion of broadband network in the counties, which are characterized by low commercial potential;

2. expanding directory of digital services in the eGovernment;

3. sharing data from the public resources for commercial purposes;

4. raising information, IT and functional competences among people who occasionally use information and communication technologies.

Ad 1.

For the digital economy to exist, the basic condition is access to the Internet. At the same time, due to more and more advanced applications, requiring the collection of more resources, it is necessary to develop broadband connections. Links of this type allow for easy media consumption, even in the case of streaming movies or other "heavy" files. On the other hand, building/expanding broadband Internet access is not a cheap task. 
For the implementation of the construction of a broadband network, it is necessary to obtain the appropriate formal consents, purchase the necessary materials, obtain human resources, and carry out construction works. Commercial entities do not undertake to build this type of infrastructure in areas that do not provide a return on investment over a certain period of time.

As a consequence, there are so-called "white spots", which are areas without universal access to fast links. To counteract this, measure 1.1 was invented. This activity is de facto the foundation for all other digital services and indirectly determines the use of the benefits of digital transformation by all (or almost all) citizens on similar terms. Thus, priority axis 1 indirectly contributes to the implementation of the digital transition.

\section{Ad 2.}

The cessation of the existing paper document flow and the creation of public online services are actions taken by public institutions within the framework of electronic administration. E-administration is characterized by many advantages for users (both on the side of clients and the offices themselves), as well as on the other hand by certain defects or barriers (Ministerstwo Cyfryzacji, 2016).

From the perspective of digital transformation, e-government is getting used to the digital information exchange standard. Expanding the catalog of public services available via the Internet indirectly translates into identified trends of digital transformation, primarily through the change of purchasing behavior, but also the creation of advanced e-services accompanying the e-services (algorithms, new business models, etc.)

\section{Ad 3.}

Interoperability of public registers, the use of public data by commercial entities - is an example of activities characteristic of the second OPDP axis. All these activities have a common feature - they allow making decisions based on fuller data. New business opportunities emerge from launching public data.
For example, the provision of flight data in the Polish airspace enables the launch of a commercial e-service for forecasting free slots at particular airports. In this sense, inclusion in the activities of the second axis is directly in the proposed scheme of the components of digital transformation.

Ad 4.

Increasing the level of digital competences is a sine qua non condition for the development of digital economy. As already mentioned in the study, the modern world requires citizens to gauge a certain level of digital skills. These skills can be divided as follows (Jasiewicz, et al., 2015):

1) information (skills allowing the user to determine when information is needed and to search, evaluate and use information from various sources);

2) IT (skills in using a computer and other electronic devices, using the Internet and using various types of applications and software, as well as creating digital content;

3) functional (the ability to apply information and communication technologies to solve problems of various aspects of everyday life, such as health, work, finances, etc.).

The implementation of the OPDP serves to increase the information, IT and functional competence. What is particularly worth emphasizing is that the program directs support to people from the two ends of the continuum, that is, people who are not able to use the Internet (e.g., seniors) or people who want to improve their IT (programming) skills. In this way, priority axis III directly affects the boosting of digital transformation.

The above analysis shows an indirect and direct impact of the OPDP on the pace of implementation of digital transformation. As a kind of summary of this analysis thread, we can propose an "impact map" showing the nature of the interaction between ODPD and digital transformation. Fig. 2 reflects the nature of the interaction between measures under ODPD and the dynamization of the digital transition. 


\begin{tabular}{|c|c|c|c|c|c|c|c|c|c|}
\hline \multirow{2}{*}{ Trends of Digital transformation } & \multicolumn{9}{|c|}{ OPDP measures } \\
\hline & 1.1 & 2.1 & 2.2 & 2.3 & 2.4 & 3.1 & 3.2 & 3.3 & 3.4 \\
\hline Change in buying behavior & I & I & & & & I & & & I \\
\hline Automation and autonomy & & I & I & $\mathrm{I}$ & I & & & & \\
\hline Comprehensive/up-to-date data & I & I & I & $\mathrm{D}$ & $\mathrm{D}$ & & & & \\
\hline Changes in business models & & I & I & $\mathrm{D}$ & $\mathrm{D}$ & & & & \\
\hline $\begin{array}{r}\text { The emergence of new segments } \\
\text { of the economy }\end{array}$ & & I & & & $\mathrm{D}$ & & & & \\
\hline Improving digital competences & & I & $\mathrm{I}$ & & & $\mathrm{D}$ & $\mathrm{D}$ & $\mathrm{D}$ & \\
\hline
\end{tabular}

Key: I - indirect influence, D - direct influence

Figure 2. The nature of the ODPD's influence on the dynamization of digital transformation (Source: Own elaboration)

Fig. 2 illustrates the positive effect of ODPD on accelerating the pace of implementation of digital transformation. Any single inhibitor for digital passage has not been identified within the OPDP.

\section{Conclusion}

In the current market, technological and social conditions, digital transformation is a process that is currently happening all the time. Individual countries are trying in an efficient and effective way to switch from traditional economy to digital economy. The Operational Program Digital Poland, which is characterized in this paper, is an example of a formalized program that is to accelerate the transition to the digital economy.

ODPD responds to the challenges of digital transformation through its material scope (fixed priority axes and measures included in them). The analysis of the "impact map" indicates that ODPD contributes to accelerating the pace of implementation of digital transformation in Poland. However, the analysis of the "impact map" leads to the conclusion that the indirect nature of the impact is definitely prevalent. The indirect impact is specific to the 14 identified relationships between ODPD and the digital transition. At the same time, direct influence occurs in 8 relationships. This means that ODPD creates more favorable conditions for digital transformation than it directly affects its acceleration. This, of course, has certain consequences for the pace of change.

The adoption of such goals and not others, and the scope of the substantive OPDP slows down the transition to the digital economy. It seems that for a program strictly focused on information and communication technologies, the ODPD setting was too conservative.

The articulated deduction is strengthened by the financial allocation structure. At the halfway point of the ODPD's functioning, $67.33 \%$ of the budget is absorbed by Measure 1.1. Ultimately, according to the plan, almost $47 \%$ of the program budget was allocated to Measure 1.1. This means that the construction of infrastructure has priority, both in the sense of the moment of spending funds and volume.

Infrastructure is a necessary condition, but it is not enough that a digital transition will permanently appear in Poland. It seems that the funds allocated for the improvement of digital competences and the provision of information from the public sector are too small. In these areas, there is a direct interaction between ODPD and digital transformation. 
The use of a larger percentage of program funds for these activities could significantly accelerate the digital transformation. Of course, the author realizes that the success of the program lies in the details. For example, the quality of training translates into the durability of remembering new skills.

At this point, one should also ask a question that comes up normally with the use of public support. Do the funds allocated improve the living conditions of the citizens or give a permanent pro-development impulse (Gorzelak, et al., 2013). The first axis, focusing expenses on the construction of the broadband Internet access infrastructure, carries changes on the demand (users) and supply side (companies, institutions). And in both cases, the use of digital content grows, digital competences grow, which leads to the development of selected market segments.

Of course, there will be a certain percentage of users who sacrifice their time only for secondary consumption. However, on a balance, this factor should make the development of the digital economy more dynamic.

The implementation of Axis 2 and 3 is clearly developing. This is due to the fact that disclosure of data from public registers will create new economic ventures or even new sectors. E-administration will get accustomed to electronic data exchange. A higher level of digital competence will contribute to the acceleration of the economy.

Therefore, it is possible so to put forward a hypothesis, that OPDP has a more pro-developmental character than a consumer character, which, however, requires further dedicated research. The above conclusion, however, is in line with the results of studies confirming the positive impact of ICT on economic development.

At the moment (end of 2017), the results of OPDP implementation are unknown. Due to the time of implementation of co-financed projects, the first real results will appear practically in 2018, while the complete results would be available after 2020 . In addition, there may be delays in the implementation of selected projects. In particular, the above note refers to projects implemented by government institutions (due to their complexity).
This will delay the dynamic effect of the digital economy. On the other hand, without OPDP launching, one of the factors that would boost the digital transformation would surely go away. In addition, each major project has its implementation time, which is associated with a period of waiting for results.

\section{$7 \quad$ References}

[1] Bracken M., 2016. What We Mean When We Say "Digital". [online] Available at: <https://digit alblog.coop.co.uk/2016/06/14/what-we-meanwhen-we-say-digital/> [Accessed 20 December 2017].

[2] Cap Gemini, MIT Sloan Management, 2011. Digital Transformation: A Roadmap for Billion. [online] Available at: <https://www.capgemini .com/wp-content/uploads/2017/07/Digital_Trans formation_A_Road-Map_for_Billion-Dollar Organizations.pdf> [Accessed 20 December 2017]. [D]

[3] Christensen, J., 2016. Digital Economics: The Digital Transformation of Global Business. Copenhagen: Books on Demand.

[4] Combe C., 2006. Introduction to e-Business. Management and Strategy. Burlington: Butterworth-Heinemann.

[5] Digital Transformation, 2017. Cap Gemini Consulting. [online] Available at: <http://www. capgemini.com/consulting/service/digital-transfo rmation/\#> [Accessed 20 December 2017].

[6] Digital Transformation Initiative, 2017. World Economic Forum and Accenture. [online] Available at: <http://reports.weforum.org/digitaltransformation/wp-content/blogs.dir/94/mp/files/ pages/files/dti-executive-summary-website-vers ion.pdf $>$ [Accessed 20 December 2017].

[7] Eggers, W.D., Bellman, J., 2016. The Journey to Government's Digital Transformation. Deloitte University Press. [online] Available at: $<$ https://www2.deloitte.com/uk/en/pages/publicsector/articles/the-journey-to-governments-digi tal-transformation.html $>$ [Accessed 20 December 2017]. 
[8] European Commission, 2010. EUROPE 2020. A Strategy for Smart, Sustainable and Inclusive Growth. COM(2010) 2020, Brussels.

[9] European Commission, 2014. The EU Explained: Digital Agenda for Europe. Brussels.

[10] Forbes Insights, 2017. How to Win at Digital Transformation. Insights from a Global Survey of Top Executives. [online] Available at: $<$ https://images.forbes.com/forbesinsights/hds_d igital_maturity/HowToWinAtDigitalTransform ation.pdf $>$ [Accessed 20 December 2017].

[11] Gorzelak G., Płoszaj A., Smętkowski M., 2013. Środki unijne - pierwsze oceny. Seminarium EUROREG. (EU funds - first evaluations. EUROREG Seminar). [online] Available at: $<$ http://www.euroreg.uw.edu.pl/dane/web_euror eg_seminary_files $/ 593 /$ gorzelak_srodki_ue a_rozwoj_16_01_2014.pdf> [Accessed 20 December 2017].

[12] Hanelt, A., Piccinini, E., Gregory, R.W., Hildebrandt, B., \& Kolbe, L.M., 2015. Digital Transformation of Primarily Physical IndustriesExploring the Impact of Digital Trends on Business Models of Automobile Manufacturers. Proceedings der 12. Internationalen Tagung Wirtschaftsinformatik (WI 2015), Osnabrück, pp. 1313-1327.

[13] Hanna, N.K., 2016. Mastering Digital Transformation: Towards a Smarter Society, Economy, City and Nation. Bingley: Emerald Group Publishing.

[14] Herbert, L., 2017. Digital Transformation: Build Your Organization's Future for the Innovation Age. London: Bloomsbury Publishing.

[15] Hołubowicz, W., 2013. Raport z ewaluacji exante Programu Operacyjnego dotyczacego rozwoju cyfrowego. (Report on ex-ante Evaluation of the Operational Program on digital Development). Poznań: ITTI. [online] Available at: $<$ https://cppc.gov.pl/wp-content/uploads/POPC Program_Zal_3_4032015. pdf $>$ [Accessed 20 December 2017].

[16] Karatzogianni, A., Nguyen, D., \& Serafinelli, E. eds., 2016. The Digital Transformation of the Public Sphere: Conflict, Migration, Crisis and Culture in Digital Networks. London: Springer.

[17] Klimczuk, A., Jasiewicz, J., Filiciak, M., Mierzecka, A., Śliwowski, K., A., Kisilowska, M.,
Tarkowski, A., Zadrożny, J., 2015, Ramowy katalog kompetencji cyfrowych. (Frame Catalogue of Digital Competences). [online] Available at: https://cppc.gov.pl/wp-content/uploads/zal.-13Ramowy_katalog_kompetencji_cyfrowych .pdf [Accessed 20 December 2017].

[18] Knickrehm, M., Berthon, B., Daugherty, P., 2016. Digital Disruption: The Growth Multiplier, Optimizing Digital Investments to Realize Higher Productivity and Growth. Accenture, [online] Available at: <https://www.accenture. com/us-en/insight-digital-disruption-growth-mul tiplier> (accessed on 2017.12.14).

[19] Lucas, H.C., Agarwal, R., Clemons, E.K., El Sawy, O.A., Weber, B., 2013. Impactful Research on Transformational Information Technology: An Opportunity to Inform New Audiences. MIS Quarterly, Vol. 37, No. 2, pp. 371-382.

[20] Mazzone, D.M., 2014. Digital or Death: Digital Transformation: The Only Choice for Business to Survive Smash and Conquer. Mississauga: Smashbox Consulting Inc.

[21] Ministerstwo Cyfryzacji, 2016. E-administracja w oczach internautów - raport z badania 2016. (E-administration in the Eyes of Internet Users Report From the 2016 Study). [online] Available at: $\quad<$ https://www.gov.pl/cyfryzacja/e-admi nistracja-w-oczach-internautow-raport-z-badan ia-2016> [Accessed 20 December 2017].

[22] Ministerstwo Cyfryzacji, 2017. Lista dofinansowanych projektów. Stan na 30 września 2017. (List of co-Financed Projects. As of September 30, 2017.). [online] Available at: $<$ http://www.polskacyfrowa.gov.pl/media/44827 /POPC_Lista_projektow_2014_2020_04102017. $\mathrm{xlsx}>$ [Accessed 20 December 2017].

[23] Ministerstwo Cyfryzacji, 2017. O Programie Polska Cyfrowa - stan na 2 października 2017 r. (About the Digital Poland Program - as of October 2, 2017). [online] Available at: $<$ https://www.polskacyfrowa.gov.pl/media/4517 1/POPC_Stanwdrazania _11102017. pdf $>$ [Accessed 20 December 2017].

[24] Ministerstwo Rozwoju, 2017. Szczegółowy opis osi priorytetowych Programu Operacyjnego Polska Cyfrowa na lata 2014-2020. Wersja z maja 2017 roku. (A Detailed Description of the 
Priority Axes of the Operational Program Digital Poland for the Years 2014-2020. Version from May 2017). Warszawa.

[25] Ministry of Infrastructure and Development, 2014. Operational Programme Digital Poland for 2014-2020. Version approved by the European Commission on 5 December 2014. Warsaw.

[26] Operational Programme Digital Poland for 2014-2020, 2014. Version approved by the European Commission on 5 December 2014, the European Commission, Brussels.
[27] Regional Policy, 2013. OP Digital Poland. European Commission. Brussels. [online] Available at: <http://ec.europa.eu/regional_policy /en/atlas/programmes/2014-2020/poland/2014 pl16rfop002> [Accessed 20 December 2017].

[28] Soule, D.L., Puram, A.D., Westerman, G.F., Bonnet, D., 2016. Becoming a Digital Organization: The Journey to Digital Dexterity. MIT Center for Digital Business Working Paper, \#301. pp.1-26. 